Mastuti Widianingsih, Dian Catur Setyorini. (2019). Identifikasi Staphulococcus Aureus pada Abon sapi di Pasar Pahing Kota Kediri. Journal Bioeksperimen. Vol. 5 (2) Pp. 99-105. Doi: 10.23917/bioeksperimen.v5i2.2795

\title{
IDENTIFIKASI STAPHYLOCOCCUS AUREUS PADA ABON SAPI DI PASAR PAHING KOTA KEDIRI
}

\author{
Mastuti Widianingsih", Dian Catur Setyorini \\ Institut Ilmu Kesehatan Bhakti Wiyata \\ *E-mail: widianingsihmastuti910224@gmail.com
}

\begin{abstract}
Contamination of processed beef foods such as abon can be caused by various types of microbes, one of which is Staphylococcus aureus. Staphylococcus aureus can cause various infections, both on the skin, gastrointestinal tract, or endocarditis. The objective of this research was to determine the presence of Staphylococcus aureus in beef abon sold in Pahing Market, Kediri. Abon used is non-branded beef abon which is as many as 10 samples obtained by total sampling technique. Samples were tested by observation of colony morphology through Gram staining, mannitol fermentation test, catalase and coagulase test, and acetoin test. The samples were inoculated on Broth $\mathrm{NaCl}$ (ink. 24 hour-37 ${ }^{\circ} \mathrm{C}$ ), then inoculated on MSA (ink. 24 hour $-37^{\circ} \mathrm{C}$ ), and VP (ink. $2 \times 24$ hours $-37^{\circ} \mathrm{C}$ ). Catalase and coagulase tests were carried out by taking colonies on MSA media. The results showed that there were 9 abon samples contaminated with Staphylococcus aureus as indicated by Gram positive staining results, positive (perfect) mannitol fermentation, and positive acetoin, catalase, and coagulase test. The causes of contamination are contaminated abon ingredients, the manufacturing process using less sterile tools, poor handling and processing, processing food with dirty hands, food stored without cover, sick food processors, and dirty markets.
\end{abstract}

Keywords: Abon, contamination, catalase, coagulase, Staphylococcus aureus

\section{Pendahuluan}

Dewasa ini, banyak penyakit yang disebabkan oleh bakteri dengan melibatkan berbagai agen perantara, seperti udara, air, tanah, makanan, minuman, ataupun barang-barang lainnya. Genus Staphylococcus, khususnya Staphylococcus aureus ditemukan dapat menyebabkan kontaminasi pada daging se'i sapi, sosis babi (Rahayu dkk, 2014), ayam broiler (Lowder et al., 2009) serta olahan ikan asap (Karimela dkk, 2017) yang tidak bermerk. Proses pengolahan makanan tidak bermerk umumnya dilakukan secara tradisional sehingga dapat meningkatkan risiko kontaminasi Staphylococcus aureus (Salasia dkk, 2009).

Kontaminasi Staphylococcus aureus mengakibatkan berbagai macam infeksi klinis, seperti bakterimia, infeksi kulit, infeksi saluran pencernaan (Thomer et al., 2016), endokarditis, osteoartikular, dan pleuropulmonari (Tong et al., 2015). Pemeriksaan adanya kontaminasi dapat dilakukan dengan identifikasi secara bakteriologi, yaitu melalui uji morfologi (pewarnaan Gram), fermentasi manitol (Manitol Salt Agar), koagulase, katalase, dan uji produksi asetoin (Voges-Proskauer) (Windria et al., 2016).

Abon menjadi salah satu produk olahan daging sapi yang mudah terkontaminasi. Sejauh ini, belum ada penelitian yang mengungkapkan adanya Staphylococcus aureus pada abon sapi, khususnya yang dijual di Pasar Pahing, Kota Kediri. Kondisi penyimpanan dan pasar yang kurang baik dapat mendukung terjadinya kontaminasi. Selain itu, kandungan nutrisi tinggi yang dimiliki abon, dapat dijadikan sebagai sumber nutrisi dan agen pertumbuhan bagi mikroba. Penelitian ini bertujuan untuk mengetahui adanya Staphylococcus aureus pada abon sapi tidak bermerk yang dijual di Pasar Pahing, Kota Kediri.

\section{Metode Penelitian}

Keseluruhan penelitian dilakukan pada bulan Februari-Maret 2017. Pengambilan sampel penelitian dilakukan di Pasar Pahing Kota Kediri, sedangkan pengujian sampel 
dilakukan di Laboratorium Bakteriologi Institut Ilmu Kesehatan Bhakti Wiyata Kediri. Sampel yang digunakan berupa 10 abon sapi tidak bermerk dan penentuan jumlah sampel dilakukan dengan teknik total sampling. Desain penelitian berupa deskriptif analitik dengan melibatkan 2 variabel yaitu variable bebas dan variable terikat. Variabel bebas yang digunakan yaitu Staphylococcus aureus, sedangkan abon sapi sebagai variabel terikat.

Alat yang digunakan meliputi neraca analitik Merck, spatel, beaker glass Pyrex, erlenmeyer Pyrex, gelas ukur Iwaki, ose bulat, autoclave Memmert (sterilisasi), incubator Memmert, mikroskop binokuler Olympus, centrifuge Hettich, centrifuge tube Iwaki, tabung reaksi, tabung Durham, dan tabung Khan Pyrex, serta plate Pyrex. Bahan yang dibutuhkan yaitu aluminium foil, object glass, beef extract, pepton, $\mathrm{NaCl}$, aquadest, Manitol Salt Agar (MSA) Merck, KOH 40\%, VogesProskauer (VP), 冈-napthol 5\%, $\mathrm{H}_{2} \mathrm{O}_{2} 3 \%$, sampel darah, natrium citrate, $\mathrm{NaCl}$ fisiologis, carbol gential violet, lugol, alkohol 95\%, dan fuschine.

\section{Pengujian Sampel Penelitian}

\section{Preparasi sampel}

Sampel abon yang didapat, diberi label untuk menghindari tertukarnya data. Label yang digunakan berupa huruf yaitu abon sapi A sampai J.

\section{Sterilisasi alat dan bahan}

Seluruh alat dan bahan disterilkan dalam autoclave pada suhu $121^{\circ} \mathrm{C}$ dengan tekanan 1,5 atm selama 15 menit (Yulvizar, 2013).

\section{Pembuatan Media}

\section{a. NaCl Broth}

Media $\mathrm{NaCl}$ Broth terdiri dari beef extract (0,06 gram), pepton $(0,51$ gram), dan $\mathrm{NaCl}$ (0,1 gram) yang ditambahkan dengan $20 \mathrm{ml}$ aquadest. Media dihomogenkan, kemudian dimasukkandalam tabung (@2ml) dan sterilkan.

b. Voges-Proskauer

Pembuatan VP membutuhkan 40 $\mathrm{ml}$ aquadest dan 0,68 gram VP yang dilarutkan dalam erlenmeyer, kemudian dituang masing-masing 4 $\mathrm{ml}$ ke tabung Khan (Hemraj et al., 2013).

\section{c. Manitol Salt Agar}

Sebanyak 16,2 gram MSA dimasukkan dalam Erlenmeyer yang berisi aquadest $150 \mathrm{ml}$, selanjutnya dipanaskan hingga larutan homogen. Larutan tersebut kemudian dituang dalamplate (@15 ml), lalu disterilkan (Yulvizar, 2013).

\section{d. Plasma Sitrat}

Pembuatan plasma sitrat 3,8\% dilakukan dengan perbandingan antara darah (manusia) dan natrium citrate sebanyak 1:9. Campuran tersebut disentrifugasi selama 15 menit dengan kecepatan $1500 \mathrm{rpm}$ (Jiwintarum dkk, 2015).

\section{Inokulasi}

Sampel ditambahkan dalam tabung reaksi yang berisi $\mathrm{NaCl}$ Broth, dihomogenkan dengan centrifuge, dan diinkubasi selama $1 \times 24$ jam suhu $37^{\circ} \mathrm{C}$. Setelah itu, hasil inokulasi dilanjutkan ke media MSA serta VP (inkubasi $2 \times 24$ jam; $37^{\circ} \mathrm{C}$ ) (Adejuwon et al., 2011).

\section{Pewarnaan Gram}

Satu masa ose bakteri dihomogenkan dengan $\mathrm{NaCl}$ fisiologi kemudian dibuat apusan pada object glass, selanjutnya dikeringkan dengan fiksasi. Pewarnaan dilakukan berjenjang, yaitu dengan menambahkan 1 tetes gentian violet ( 2 menit), kemudian buang dan dilanjutkan dengan 1 tetes lugol selama 1 menit. Penambahan alkohol (1 tetes; 1 menit) pada tahap ketiga berfungsi melunturkan gentian violet. Tahap terakhir yaitu dengan pemberian fuschine (2 menit), lalu bilas dengan 
aquadest. Preparat diamati dengan mikroskop binokuler guna mengetahui morfologi bakteri (Abera et al., 2010).

\section{Uji Katalase Koagulase dan Uji VP}

a. Uji katalase

Koloni bakteri yang ada pada media MSA diambil dengan menggunakan ose bulat steril, kemudian diletakkan pada object glass dan diberi 1 tetes $\mathrm{H}_{2} \mathrm{O}_{2} 3 \%$. Hasil positif ditandai dengan terbentuknya gelembung udara (Hemraj et al., 2013; Yurdakul et al., 2013).

\section{b. Uji Koagulase (Slide Test)}

Koloni yang sama pada media MSA diletakkan pada object glass lalu ditambahkan larutan plasma sitrat. Apabila terjadi presipitasi saat dihomogenkan dengan ose bulat steril, maka disimpulkan koagulase positif (Abera et al., 2010).

c. Uji VP

Uji VP digunakan untuk mendeteksi asetoin yang dihasilkan bakteri setelah 2x24 jam inkubasi. Adanya kekeruhan menandakan adanya pertumbuhan bakteri, sedangkan produk asetoin ditunjukkan dengan adanya perubahan warna menjadi merah setelah dilakukan penambahan reagent $\mathrm{KOH} \mathrm{40 \%} \mathrm{dan} \bigotimes$-napthol 5\% (Hemraj et al., 2013).

\section{d. Interpretasi Hasil}

Hasil positif pada uji katalase dan koagulase menjadi salah satu parameter identifikasi Staphylococcus aureus. Selain itu, fermentasi manitol positif (pada media MSA), serta produksi asetoin positif juga menunjukkan adanya Staphylococcus aureus.

\section{Hasil Dan Pembahasan}

Hasil identifikasi menunjukkan ada sebanyak 9 sampel abon sapi tidak bermerk yang terkontaminasi Staphylococcus aureus (Tabel 1). Hasil tersebut diperoleh berdasarkan pengamatan morfologi dengan pewarnaan Gram (Gambar 1), hasil fermentasi manitol (Gambar 2), uji katalase (Gambar 3) dan koagulase (Gambar 4), serta uji VP (Gambar 5).

Adapun faktor yang mempengaruhi adanya kontaminasi abon dapat disebabkan oleh beberapa kemungkinan, yaitu pengambilan bahan dasar abon yang kurang baik serta proses pembuatan abon yang menggunakan alat-alat rumah tangga yang tidak bersih, penanganan, dan pengolahan yang kurang baik. Selain itu, kontaminasi juga dapat terjadi karena pengolahan makanan dengan tangan kotor, makanan yang disimpan tanpa tutup dan lembab, pengolah makanan dalam kondisi sakit, serta kondisi lingkungan tempat pemasaran yang tercemar (kotor).

Staphylococcus aureus adalah suatu bakteri yang memproduksi enterotoksin penyebab keracunan (Lowder et al., 2009). Keracuan ditandai dengan gejala mual, muntah, kejang perut, bahkan sampai diare. Bakteri tersebut sering ditemukan pada makanan-makanan, merupakan bakteri coccus Gram positif, dan termasuk dalam family Micrococcaceae. Tumbuh secara anaerobik fakultatif dengan membentuk kumpulan sel-sel seperti buah anggur dan umum dijadikan indikator higienitas pengolahan makanan. Staphylococcus aureus tahan tehadap kadar garam dan memproduksi koagulase (Ahmetagic et al., 2013; Frey et al., 2013). Uji koagulase dapat dijadikan sarana identifikasi dan penentuan spesies Staphylococcus aureus (Keteete et al., 2010). 
Tabel 1. Hasil Identifikasi Staphylococcus aureus pada Abon Sapi

\begin{tabular}{|c|c|c|c|c|c|c|c|c|}
\hline \multirow[b]{2}{*}{ No } & \multirow[b]{2}{*}{$\begin{array}{l}\text { Abon } \\
\text { Sapi }\end{array}$} & \multicolumn{2}{|c|}{ Morfologi Koloni } & \multicolumn{4}{|c|}{ Macam Uji } & \multirow[b]{2}{*}{$\begin{array}{c}\text { Keteran- } \\
\text { gan }\end{array}$} \\
\hline & & $\begin{array}{c}\text { Warna/ } \\
\text { Sifat }\end{array}$ & Bentuk & MSA & VP & $\begin{array}{c}\text { Kata- } \\
\text { lase }\end{array}$ & $\begin{array}{c}\text { Koagu- } \\
\text { lase }\end{array}$ & \\
\hline 1 & $\mathrm{~A}$ & $\overline{U / G P}$ & Coccus & $\mathrm{FM+}$ & + & + & + & S. aureus \\
\hline 2 & B & U/GP & Coccus & $\mathrm{FM}+$ & + & + & + & S. aureus \\
\hline 3 & $\mathrm{C}$ & U/GP & Coccus & $\mathrm{FM}+$ & + & + & + & S. aureus \\
\hline 4 & $\mathrm{D}$ & U/GP & Coccus & FM+ & + & + & + & S. aureus \\
\hline 5 & $\mathrm{E}$ & U/GP & Coccus & $\mathrm{FM+}$ & + & + & + & S. aureus \\
\hline 6 & $\mathrm{~F}$ & U/GP & Coccus & $\mathrm{FM}_{+}$ & + & + & + & S. aureus \\
\hline 7 & G & - & - & - & - & - & - & - \\
\hline 8 & $\mathrm{H}$ & U/GP & Coccus & $\mathrm{FM}+$ & + & + & + & S. aureus \\
\hline 9 & I & U/GP & Coccus & $\mathrm{FM+}$ & + & + & + & S. aureus \\
\hline 10 & $\mathrm{~J}$ & U/GP & Coccus & $\mathrm{FM+}$ & + & + & + & S. aureus \\
\hline
\end{tabular}

Keterangan: FM+: Fermentasi manitol positif; GP: Gram positif; MSA: Manitol Salt Agar; $\mathrm{U}$ : berwarna ungu, -: tidak ada pertumbuhan pada $\mathrm{NaCl}$ Broth

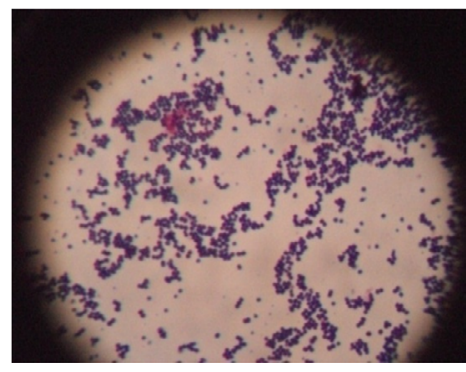

Gambar 1. Hasil Pewarnaan Gram Staphylococcus aureus

\section{Morfologi Koloni}

Pewarnaan Gram menjadi salah satu cara mengetahui morfologi koloni bakteri. Staphylococcus aureus diketahui sebagai bakteri Gram positif yang berbentuk coccus berwarna ungu (Gambar 1) (Sindhu et al., 2010; Adejuwon et al., 2011). Selain itu, bakteri Gram positif memiliki ciri umum berupa dinding sel (peptidoglikan) yang lebih tebal $(20-80 \mathrm{~nm})$ dibandingkan bakteri Gram negatif. Hal tersebut yang mengakibatkan Staphylococcus aureus memiliki tingkat pertumbuhan, tingkat infeksi, dan pola resistensi yang tinggi dibandingkan dengan bakteri Gram negatif seperti Escherichia coli (Lykov et al., 2017).

\section{Fermentasi Manitol}

Manitol Salt Agar menjadi media uji fermentasi manitol. Adanya fermentasi manitol ditandai dengan perubahan warna media yang semula merah menjadi kuning (Adejuwon et al.,
2011) akibat adanya penurunan $\mathrm{pH}$ menjadi asam (Karimela dkk, 2017). Hasil penelitian menunjukkan Staphylococcus aureus yang didapat memiliki kemampuan fermentasi manitol sempurna (media menjadi kuning keseluruhan) dengan koloni berwarna putih (Gambar 2).

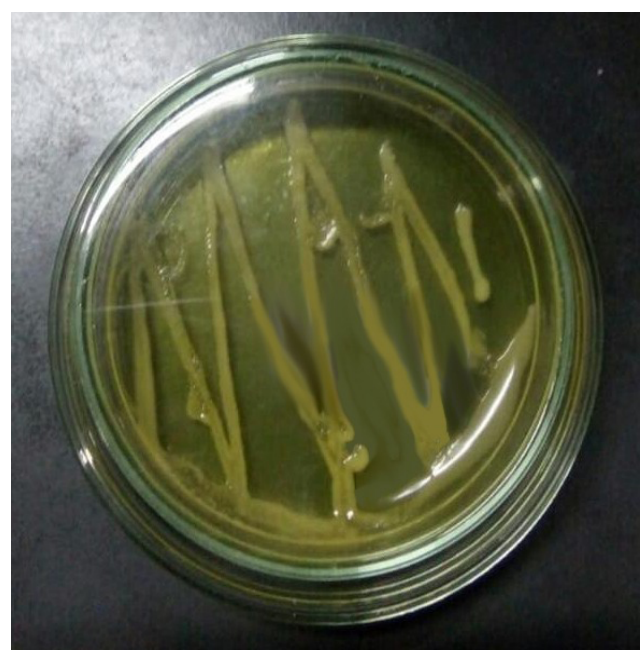

Gambar 2. Uji fermentasi manitol positif pada MSA 


\section{Uji Katalase}

Uji katalase digunakan untuk membedakan genus Staphylococcus dan Streptococcus (Todar, 2005; Karimela dkk, 2017). Gelembung udara yang terbentuk pada uji katalase (Gambar 3) menunjukkan hasil katalase positif untuk Staphylococcus (Sindhu et al., 2010) merupakan hasil hidrolisis $\mathrm{H}_{2} \mathrm{O}_{2}$ menjadi molekul air dan oksigen (Hemraj et al., 2013). Hidrolisis $\mathrm{H}_{2} \mathrm{O}_{2}$ distimulasi oleh enzim katalase yang terletak pada permukaan membran sel bakteri Staphylococcus (Hemraj et al., 2013; Yurdakul et al., 2013). Reaksi tersebut berlangsung sebagai mekanisme pertahanan diri bakteri terhadap $\mathrm{H}_{2} \mathrm{O}_{2}$ yang bersifat toksik (Locke et al., 2012).

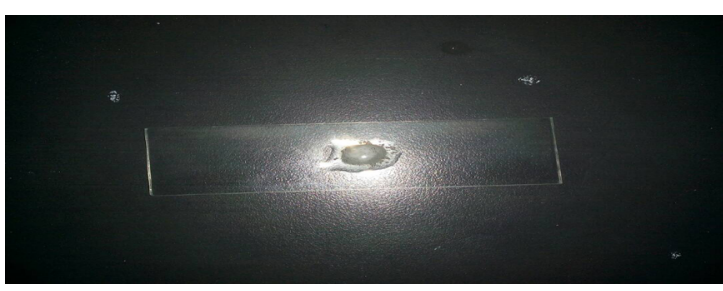

Gambar 3. Uji Katalase

\section{Uji Koagulase}

Staphylococcus aureus umumnya memiliki hasil uji koagulase positif, namun ada pula yang menunjukkan hasil negatif. Berdasarkan hasil penelitian Yurdakul et al. (2013) menyatakan bahwa hasil negatif menunjukkan bahwa Staphylococcus oportunistik. Pada penelitian ini, dihasilkan koagulase positif yang ditunjukkan dengan adanya presipitasi (gumpalan) (Gambar 4). Uji koagulase slide (Slide Coagulase Test) SCT) dilakukan dengan mendeteksi adanya faktor penggumpalan yang bereaksi secara langsung dengan fibrinogen yang terikat pada plasma (McAdow et al., 2011) sehingga didapatkan hasil yang lebih cepat dibandingkan uji koagulase tabung (Tube Coagulase Test/TCT) (Kateete et al., 2010).

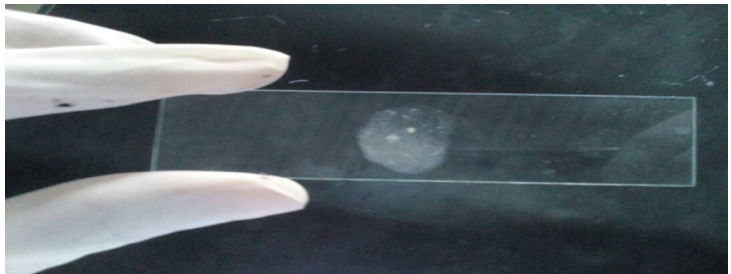

Gambar 4. Uji Koagulase

\section{Uji VP}

Deteksi asetoin melalui uji VP dilakukan dengan penambahan reagent $\mathrm{KOH} 40 \%$ dan $\alpha$-napthol 5\%. Hasil penelitian menunjukkan 9 sampel positif dengan terbentuknya cincin berwarna merah pada bagian atas media (Gambar 5). Uji tersebut ditentukan oleh kemampuan bakteri membentuk asetoin (asetiletilkarbinol) melalui pemecahan glukosa. Asetoin selanjutnya bereaksi dengan $\alpha$-napthol 5\% dan $\mathrm{KOH} 4 \%$ sehingga menghasilkan warna merah pada media (Hemraj et al., 2013).

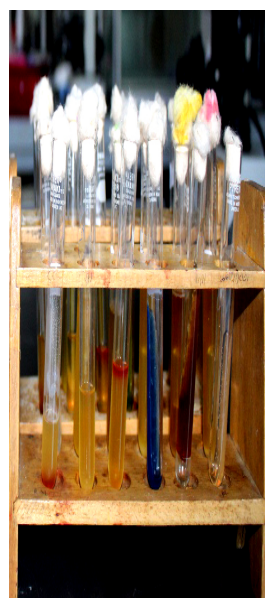

Gambar 5. Uji VP positif ditunjukkan dengan adanya cincin merah di bagian atas media

\section{Simpulan}

Abon sapi yang dijual di Pasar Pahing Kota Kediri positif terkontaminasi Staphylococcus aureus dengan persentase $90 \%$. 


\section{Daftar Pustaka}

Abera, M., Demie, B., Aragaw, K., Regassa, F., \& Regassa, A. (2010). Isolation and identification of Staphylococcus aureus from bovine mastitic milk and their drug resistance patterns in Adama town, Ethiopia. Journal of Veterinary Medicine and Animal Health, 2(3), 29-34.

Adejuwon, A. O., Ogunkanmbi, D., Adejumoke, M., \& Johnson, B. (2011). Staphylococcus aureus isolated from septic caesaerean wound at Ile Ife Nigeria: Antibiotics susceptibility patterns. International Journal of Medicine and Medical Sciences, 3(5), 149-154.

Ahmetagic, A., Fatima, N., Sead, A., Rakovac-Tupkovic, L., \& Porobic-Jahic, H. (2013). Etiology of peritonitis. Journal Medical Archives, 64(4), 278-281.

Frey, Y., Rodriguez, J. P., Thomann, A., Schwendener, S., \& Perreten, V. (2013). Genetic characterization of antimicrobial resistance in coagulase-negative staphylococci from bovine mastitis milk. Journal of Dairy Science, 96(4), 2247-2257. https://doi.org/10.3168/ JDS.2012-6091

Hemraj, V., Diksha, S., \& Avneet, G. (2013). A review on commonly used biochemical test for bacteria. Innovare Journal of Life Science, 1(1), 1-7. Retrieved from http://innovareacademics. in/journals/index.php/ijls/article/viewFile/30/36

Jiwintarum, Y., Srigede, L., \& Rahmawati, A. (2018). Perbedaan Hasil Uji Koagulase Menggunakan Plasma Sitrat Manusia 3,8\%, Plasma Sitrat Domba 3,8\%, dan Plasma Sitrat Kelinci 3,8\% pada Bakteri Staphylococcus aureus. Jurnal Kesehatan Prima, 9(2), 1559-1569. https://doi. org/10.32807/JKP.V9I2.77

Karimela, E. J., Ijong, F. G., \& Dien, H. A. (2017). Karakterisasi Staphylococcus aureus yang Diisolasi dari Ikan Asap Pinekuhe Hasil Olahan Tradisional Kabupaten Sangihe. Jphpi, 20(1), 188-198. https://doi.org/10.17844/jphpi.2017.20.1.356

Kateete, D. P., Kimani, C. N., Katabazi, F. A., Okeng, A., Okee, M. S., Nanteza, A., ... Najjuka, F. C. (2010). Identification of Staphylococcus aureus: DNase and Mannitol salt agar improve the efficiency of the tube coagulase test. Annals of Clinical Microbiology and Antimicrobials, 9(1), 23. https://doi.org/10.1186/1476-0711-9-23

Locke, T., Keat, S., Walker, A., \& Mackinnon, R. (2012). Microbiology and Infectious Diseases on The Move (First Edit). London: CRC Press.

Lowder, B. V, Guinane, C. M., Ben Zakour, N. L., Weinert, L. A., Conway-Morris, A., Cartwright, R. A., ... Fitzgerald, J. R. (2009). Recent human-to-poultry host jump, adaptation, and pandemic spread of Staphylococcus aureus. Proceedings of the National Academy of Sciences of the United States of America, 106(46), 19545-19550. https://doi.org/10.1073/pnas.0909285106

Lykov, A., Gaidul, K., Goldina, I., Konenkov, V., Kozlov, V., Lyakhov, N., \& Dushkin, A. (2017). Silica Nanoparticles as a Basis for Efficacy of Antimicrobial Drugs. Nanostructures for Antimicrobial Therapy, 551-575. https://doi.org/10.1016/B978-0-323-46152-8.00025-1

McAdow, M., Kim, H. K., DeDent, A. C., Hendrickx, A. P. A., Schneewind, O., \& Missiakas, D. M. (2011). Preventing Staphylococcus aureus Sepsis through the Inhibition of Its Agglutination in Blood. PLoS Pathogens, 7(10), e1002307. https://doi.org/10.1371/journal.ppat.1002307

Rahayu, N. P. N., Kawuri, R., \& Suriani, N. L. (2014). Uji Keberadaan Staphylococcus aureus pada Sosis Tradisional (Urutan) yang Beredar Di Pasar Tradisional Di Denpasar, Bali. SIMBIOSIS, 2(1). Retrieved from https://ojs.unud.ac.id/index.php/simbiosis/article/view/9497

S., S., Khusnan, \& Sugiyono. (2009). Distribusi gen enterotoksin Staphylococcus aureus dari susu

104-Identifikasi Staphulococcus Aureus... 
segar dan pangan asal hewan. Jurnal Veteriner, 10, 111-117.

Sindhu, N., Sharma, A., \& Jain, V. K. (2010). Coagulase gene based molecular detection of Staphylococcus aureus directly from mastitic milk samples of murrah buffalo. Buffalo Bulletin, 29(1), 62-69.

Thomer, L., Schneewind, O., \& Missiakas, D. (2016). Pathogenesis of Staphylococcus aureus Bloodstream Infections. Annual Review of Pathology: Mechanisms of Disease, 11(1), 343-364. https://doi.org/10.1146/annurev-pathol-012615-044351

Todar, K. (2005). Todar's Online Textbook of Bacteriology. Retrieved June 19, 2019, from http:// textbookofbacteriology.net/

Tong, S. Y. C., Davis, J. S., Eichenberger, E., Holland, T. L., \& Fowler, V. G. (2015). Staphylococcus aureus infections: epidemiology, pathophysiology, clinical manifestations, and management. Clinical Microbiology Reviews, 28(3), 603-661. https://doi.org/10.1128/CMR.00134-14

Windria, S., Widianingr, D. C., \& Salasia, S. I. O. (2016). Identification of Staphylococcus aureus and Coagulase Negative Staphylococci Isolates from Mastitis Milk of Etawa Crossbred Goat. Research Journal of Microbiology, 11(1), 11-19. https://doi.org/10.3923/jm.2016.11.19

Yulvizar, C. (2013). Isolation and Identification of Probiotic Bacteria In Rastrelliger sp. Biospecies, 6(2), $1-7$.

Yurdakul, N. E., Erginkaya, Z., \& Unal, E. (2013). Antibiotik Resistance of Enterococci, Staphylococcus aureus Isolated from Chicken Meat Czech. Journal Food Sci, 31(1), 14-19. 